\title{
MECHANICAL DAMAGE DURING HARVEST AND LOADING AFFECT ORANGE POSTHARVEST QUALITY
}

Doi:http://dx.doi.org/10.1590/1809-4430-Eng.Agric.v35n1p 154-162/2015

\section{MARCELA MIRANDA ${ }^{1}$, POLIANA C. SPRICIGO ${ }^{2}$, MARCOS D. FERREIRA ${ }^{3}$}

\begin{abstract}
Brazil is the world's largest orange producer; however, part of this production is lost during postharvest. This loss can be minimized by controlling incidence of physical damage throughout the harvest and loading operations. Impacts can negatively modify quantitative and qualitative fruits aspects. The main goal of this study was to measure the impact magnitude in two types of harvest (manual and detachment) and during all steps from picking into bags until loading for transport to the processing industry and additionally evaluating, in laboratory, the physicochemical quality of the fruit subjected to various impacts, similar to those found in the field. In order to evaluate the impact magnitude, an instrumented sphere was used $(760 \mathrm{~mm}$, Techmark, Inc, USA). The following physico-chemical parameters were evaluated during 6-days of storage: weight loss, soluble solids contents, titratable acidity, ascorbic acid content, $\mathrm{pH}$, firmness and peel color. The greatest impacts were observed during harvest, during the detachment practice, and when loading and unloading from bulk storage, with average acceleration values between 249.5 and 531.52G. The impact incidence in oranges were responsible for reducing the soluble solids, titratable acidity, ascorbic acid and weight by to $5.5 \% ; 8.7 \% ; 4.6 \%$ and $0.5 \%$, respectively, compared to the control. Impacts during harvest and the various pre-industry manipulation steps must be controlled as they interfere in postharvest quality and physiology of 'Valência' oranges.
\end{abstract}

KEYWORDS: Citrus sinensis; instrumented sphere; manual, detachment, soluble solids.

\section{DANOS MECÂNICOS NA COLHEITA E CARREGAMENTO DE LARANJAS E QUALID ADE PÓS-COLHEITA}

RESUMO: O Brasil é o maior produtor mundial de laranjas; contudo, parte desta produção é perdida ao longo da pós-colheita. Essas perdas podem ser minimizadas controlando-se a incidência de danos físicos nas operações de colheita e carregamento. Os impactos podem alterar negativamente aspectos qualitativos e quantitativos da produção. O objetivo desta pesquisa foi mensurar a magnitude dos impactos em dois tipos de colheita (manual e derriça) e durante as etapas desde a coleta dos frutos nas sacolas até o carregamento de laranjas para indústria e, adicionalmente, avaliar em laboratório a qualidade físico-química de frutos submetidos a magnitude de impactos similares aos encontrados em campo. Para a avaliação da magnitude dos impactos, foi utilizada a esfera instrumentada $(760 \mathrm{~mm}$, Techmark, Inc, USA). Durante armazenamento por seis dias, as avaliações físico-químicas foram: perda de massa fresca, teores de sólidos solúveis, acidez titulável, teor de ácido ascórbico, pH, firmeza e coloração da casca. Os maiores impactos avaliados foram na colheita, durante a prática da derriça, e no carregamento, ao longo da transferência do armazenamento para o caminhão, com valores médios de aceleração entre 249,5 e 531,52G ( $\left.\mathrm{m} \mathrm{s}^{-2}\right)$. A incidência de impactos nas laranjas foi responsável pela redução de até 5,5\%; 8,7\%; 4,6\% e 0,5 $\%$ em relação ao controle para sólidos solúveis, acidez titulável, ácido ascórbico e massa fresca, respectivamente. Impactos durante a colheita e em várias etapas anteriores a industrialização devem ser controlados, pois interferem na qualidade e na fisiologia pós-colheita de laranjas 'Valência'.

PALAVRAS-CHAVE: Citrus sinen sis; esfera instrumentada; manual, derriça, sólidos solúveis.

\footnotetext{
${ }^{1}$ Universidade Federal de São Carlos, Mestranda, Programa de Pós-Graduação em Biotecnologia, São Carlos - SP, Fone: (16) $2107-$ 2800, marcelamirandabiologia@hotmail.com.

${ }^{2}$ Universidade Federal de São Carlos, Doutoranda, Programa de Pós-Graduação em Biotecnologia, São Carlos - SP, polianaspricigo@y ahoo.com.br.

${ }^{3}$ Empresa Brasileira de Pesquisa Agropecuária, Pesquisador, Embrapa Instrumentação, São Carlos - SP, marcos.david@embrapa.br. Recebido pelo Conselho Editorial em: 09-4-2013
}

Aprovado pelo Conselho Editorial em: 09-9-2014 


\section{INTRODUCTION}

Brazil is the world's largest orange producer and therefore the Brazilian citrus production has great socioeconomic relevance (IBRAF, 2010). Orange production in Brazil reached 18.1 million tons in 2013, in which the citrus belt of Sao Paulo state was responsible for 13.5 millions. Brazil is the main orange juice exporter in the world (AGRIANUAL, 2014). Citrus production generates 230 thousand direct or indirect jobs (NEVES et al.; 2010).

The cost of harvest operations and loading is $44 \%$ of the total production and can be even more significant if added to postharvest losses (NEVES et al., 2010). Mechanical, physiological and pathological damage occurrence in harvested fruits is due to improper handling, transportation and storage in these operations (FERREIRA \& MAGALHÃES, 2008).

Fruit impact incidence influences physiological, metabolic, aroma and flavor alterations and must be monitored in order to maintain fruit quality (CHITARRA \& CHITARRA, 2005). It can also alter soluble solids contents, ascorbic acid, reducing sugars and titratable acidity and increase respiratory activity evolution (MATTIUZ \& DURIGAN, 2001). Physical damages due to impact in limes induced weight loss, color changes, and a decrease of $9.5 \% ; 11.4 \%$ and $5.9 \%$ for soluble solids, titratable acidity and ascorbic acid, respectively (DURIGAN et al., 2005).

Manual harvest causes low impact incidence in fruits. However, it is an uncomfortable activity for harvesters due to repetitive and continuous movements with ladders and harvesting bags (CORREAA et al., 2009). Fruit detachment, before gathering, facilitates harvest for pickers, but it is not recommended due to ground impact that can damage and contaminate, decreasing final product quality (COSTA, 2013).

Large bags $(540 \mathrm{~kg})$ are used on orange farms and enable mechanical transfer to trucks used for internal transport and delivery to industries or even for farm bulk storage (TACHIBANA\&RIGOLIN, 2002). Fruits impact on rigid surfaces of the interchange points tends to be significant (FERREIRA et al., 2009).

This study aimed to measure the impact magnitude during orange harvest while picking into bags and loading and to evaluate fruits subjected to similar impacts as those measured in the field and evaluate the physico-chemical quality under laboratory conditions.

\section{MATERIAL AND METHODS}

STAGE 1: Impact measurement in different types of harvest and throughout loading steps.

Evaluations were conducted in a commercial orchard of 'Valência'orange (Citrus sinensis $(\mathrm{L}$.) Osbeck), located in São Paulo state countryside, Araraquara region.

Two types of harvests were evaluated:

(I) Manual harvest: fruit removal from tree;

(II) Detachment: fallen fruits gathered from the ground;

Five transfer loading step points were evaluated:

(III) - Harvesting into bags (bags with handles transversal to the picker's body, that sustain 23-27 kg of fruit);

(IV) - Bags into big bags;

(V) - Big bags to trucks for internal transport;

(VI) - From truck to farm bulk storage and

(VII) - Truck loading for transport to ind ustry.

Impacts during harvest were quantified by maximum acceleration (MA) $\left(\mathrm{G}=9.81 \mathrm{~m} \mathrm{~s}^{-2}\right)$ with an instrumented sphere (760 mm, Techmark, Inc., Lansing, EUA). Therefore, manual and 
detachment harvest were performed through simulations using the instrumented sphere. This procedure was conducted by cutting an orange on the tree (A) at the equatorial part (B), discarding the lower half of the fruit and the pulp of the upper half $(\mathrm{C})$ and attaching the instrumented sphere (D and E) with the aid of a stretch plastic film. The pickers continued harvesting the instrumented sphere as they as it were an orange.

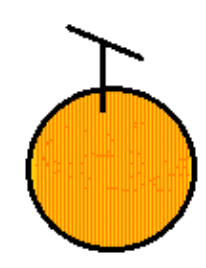

(A)

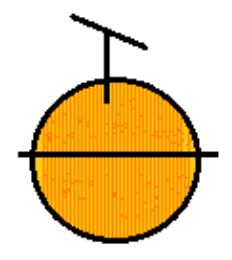

(B)

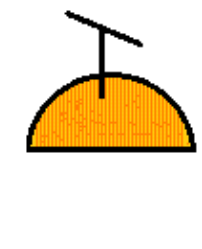

(C)

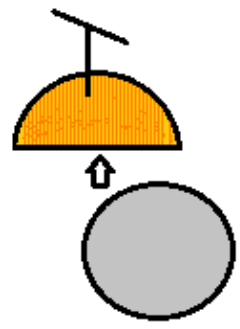

(D)

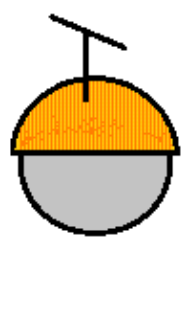

(E)

FIGURE 1. Instrumented sphere set for harvest

In order to discuss the study results, the terminology SYSTEM A indicates manual harvest via picking into bags and loading until the processing industry, while SYSTEM B indicates detachment harvest plus placing into bags and loading until the industry.

Each harvest modality and each loading step were evaluated independently 7 times and data were submitted to analysis of variance (ANOVA) with means classified by Tukey test at 5\% of probability. The data were processed in the SAS statistical package (SAS, 2011).

STAGE 2: Laboratory drop tests and orange postharvest quality evaluation.

'Valência' oranges (Citrus sinensis (L.) Osbeck) originating from the same commercial orchards located in São Paulo state, Araraquara region, were used. The fruits were harvested in the morning, packaged in bubble wrap plastic films to reduce impacts and then transported to the Postharvest Technology Laboratory at Embrapa Instrumentation, in São Carlos-SP. Fruits with no physical damage were selected with a minimum $10^{\circ}$ Brix and ratio of 9.5.

Impact values applied in treatments were based on those obtained in the first stage of this study. In this regard, impact ranges of $1000 \mathrm{G}$ representing SYSTEM A were used; 1500G representing values added in SYSTEM B; 500G and 2000G to simulate impact incidence under and over these systems.

Thus, the treatments were: control (undropped fruits); Treatment 1 (two drops at $22 \mathrm{~cm}$ height, totaling 500G); Treatment 2 (four drops, totaling $1000 \mathrm{G}$ ); Treatment 3 (six drops, totaling $1500 \mathrm{G}$ ) and Treatment 4 (eight drops, totaling 2000G). After impact, fruits were stored for 6 days at $24^{\circ} \mathrm{C} \pm 1{ }^{\circ} \mathrm{C}$ and $85 \% \mathrm{RH}$.

Impact magnitude standardizations were performed at approximately $250 \mathrm{G}$ during the preliminary tests by dropping the instrumented sphere from a height of $22 \mathrm{~cm}$ using a suction equipment, similar to a vacuum pump, developed by CAMARGO et al., (2004) on a steel plate.

Physico-chemical evaluations conducted daily were weight loss; soluble solids contents; titratable acidity, ascorbic acid content, $\mathrm{pH}$, firmness and peel color. Soluble solids content was evaluated using an digital refractometer Atago RX-5000cx while titratable acidity and ascorbic acid content were determined through titration. The $\mathrm{pH}$ values were measured using bench top $\mathrm{pH}$ meter PHS-3B (AOAC, 2010).

Firmness was determined through flattening, obtained by the equation $\mathrm{F}=\mathrm{P} / \mathrm{A}$, where $\mathrm{P}=$ probe weight $(0.914 \mathrm{kgf})$ and $\mathrm{A}=$ flattened area $\left(\mathrm{cm}^{2}\right)$, corresponding to an ellipsoid, obtaining the unit of pressure $\left(\mathrm{kgf} / \mathrm{cm}^{2}\right)$ (CALBO and NERY, 1995). 
Peel color was evaluated in a Hunter Lab 45/0-L refractometer, expressed in values of $\mathrm{L}^{*}, \mathrm{a}^{*}$ and $\mathrm{b}^{*}$, according to the system proposed by Commission Internationale de L'Eclaraige (CIE). Color was defined by three different parameters integrated in a three-dimensional diagram: $\mathrm{L}^{*}$ or lightness $(0=$ black, to $100=$ white $)$; hue angle calculated by $\tan ^{-1}=\left(\mathrm{b}^{*} / \mathrm{a}^{*}\right)$; and Chroma $(\mathrm{C})$, by the equation $C=\sqrt{ } a^{2}+b^{2}$, which indicates color saturation.

Experiments were conducted in completely randomized factorial design, consisting of two factors: five treatments (control, 500G, 1000G, 1500G and 2000G) and six samplings throughout the days. Each treatment consisted of 54 units, totaling 270 fruits. Data were submitted to analysis of variance (ANOVA) and the means classified by the Tukey test at $5 \%$ of probability. Data were also processed in the SAS statistical package (SAS, 2011).

\section{RESULTS AND DISCUSSION}

STAGE 1: Impact measurement in different types of harvest and throughout loading steps.

Manual harvest produced low magnitude impacts between 46.8 and $68.6 \mathrm{G}$, while detachment elevated impact values by $347 \%$ compared to manual harvest, on average corresponding to $203.4 \mathrm{G}$ (Fig. 2, I and II). Fruits subjected to impacts showed internal tissue breakdown, electrolyte leakage, and enhance degradation (MONTERO et al., 2009). Impacts occurred in limes compromised fruit marketing, causing juice vesicle (pulp) breakdown and blossom-end rot (DURIGAN et al., 2005). The detachment practice facilitates microbiological contamination of the fruit and increases disease susceptibility (SMILANICK et al., 2008).

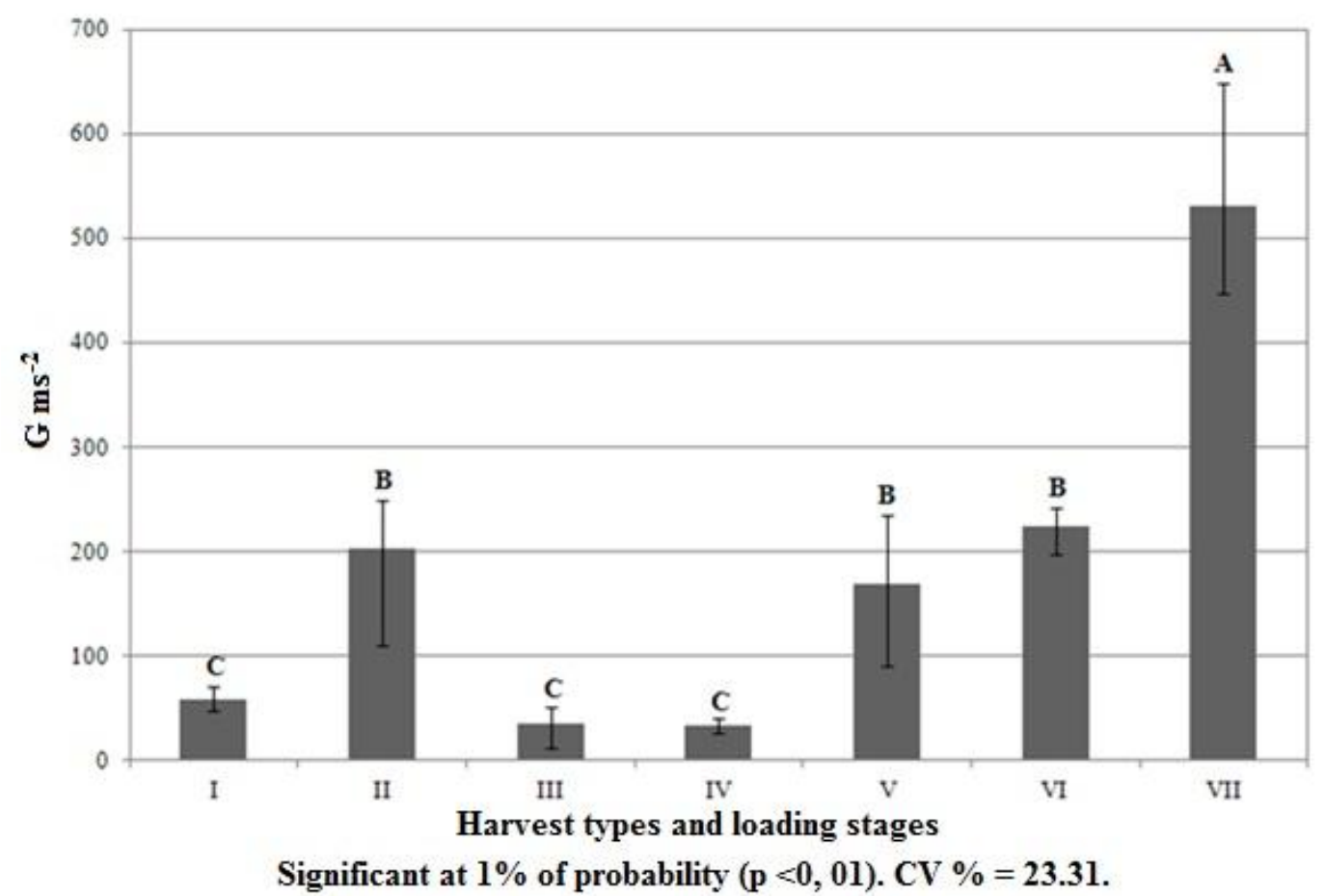

Significant at $1 \%$ of probability $(\mathrm{p}<0,01) . \mathrm{CV} \%=23.31$.

Figure 2. Impacts $\left(\mathrm{G} \mathrm{ms}^{-2}\right)$ during I - Manual harvest; II - Detachment; III - Picking into bags; IV bag into big bags; V - big bags to trucks for internal transport; VI - From truck to farm bulk storage and VII - truck loading for transport to ind ustry.

In S teps III and IV, impact values varied from 27.40 to 59.20G (Fig. 2). Manual fruit removal kept fruits from injury when compared to detachment. Impact incidence had positive correlation with oleocellosis emergence, as observed in citrus sorting lines (FISCHER et al. 2009). 
Drops varying from 5 to $10 \mathrm{~m}$ occurred in Transfers $\mathbf{V}$ and VI. These excessive heights generated impact magnitudes of 100 to $250 \mathrm{G}$ (Fig. 2). During loading, the maximum acceleration variation might have been influenced due to oranges that were already stored in the truck or in bulk storage. Stored fruits might have cushioned new entry fruits, and consequently the instrumented sphere. Therefore, the first stored fruits might have received impacts from those following and injuries by compression. According to MILIND (2010), high impacts can damage fruits even if it is not possible see the symptoms, and careful handling can substantially reduce postharvest losses.

Unloading oranges from bulk storage to trucks for transport to industry (Step VII), exposed fruits to more severe impacts. Averages varied from $531.52 \pm 80.15 \mathrm{G}$, originating from drops higher than $10 \mathrm{~m}$ height (Fig. 2). Besides drop height, the rigid surface might have contributed to high impact incidence. Effective physical damage decreases can be obtained with the employment of protective surfaces, with appropriate padded materials that allow dissipation of energy produced by dropping (FERREIRA et al., 2009).

Impacts of SYSTEM A totaled an average acceleration of 1066G, in which impacts after harvest represented $94 \%$ of this value. On the other hand, in SYSTEM B, the average acceleration totaled $1256 \mathrm{G}$, in which $80 \%$ of these impacts resulted from postharvest loading (Fig. 2). Mechanical damage severity can vary according to impact number and ripening stage of harvested fruits. It is to be highlighted that impacts on orange did not cease after the fruits left the rural property, and could still happen throughout other postharvest steps.

STAGE 2: Laboratory drop tests and orange postharvest quality evaluation.

Impacted fruits lost weight when compared to the control during a six-day storage period; these losses were $0.3 \%$ higher in relation to control in fruits subjected to impacts of $1000 \mathrm{G}$ and $1500 \mathrm{G}$ (Fig. 3). Impact accumulation throughout the following steps, transportation, handling, sorting and commercialization, can add damage to those already existing. Impacts of 2000G increased fresh weight losses by $0.5 \%$ in the storage period. MONTERO et al., (2009) presented similar weight loss results with citrus fruits, in which there was a gradual decrease of fresh weight as the intensity of mechanical damage in 'Murcott' tangor and 'Rainha' tangerine increased. Weight loss results from water content decrease and can be intensified due to tissue injuries that cause physiological alterations in transpiration and respiration processes (PRUSKY, 2011). 


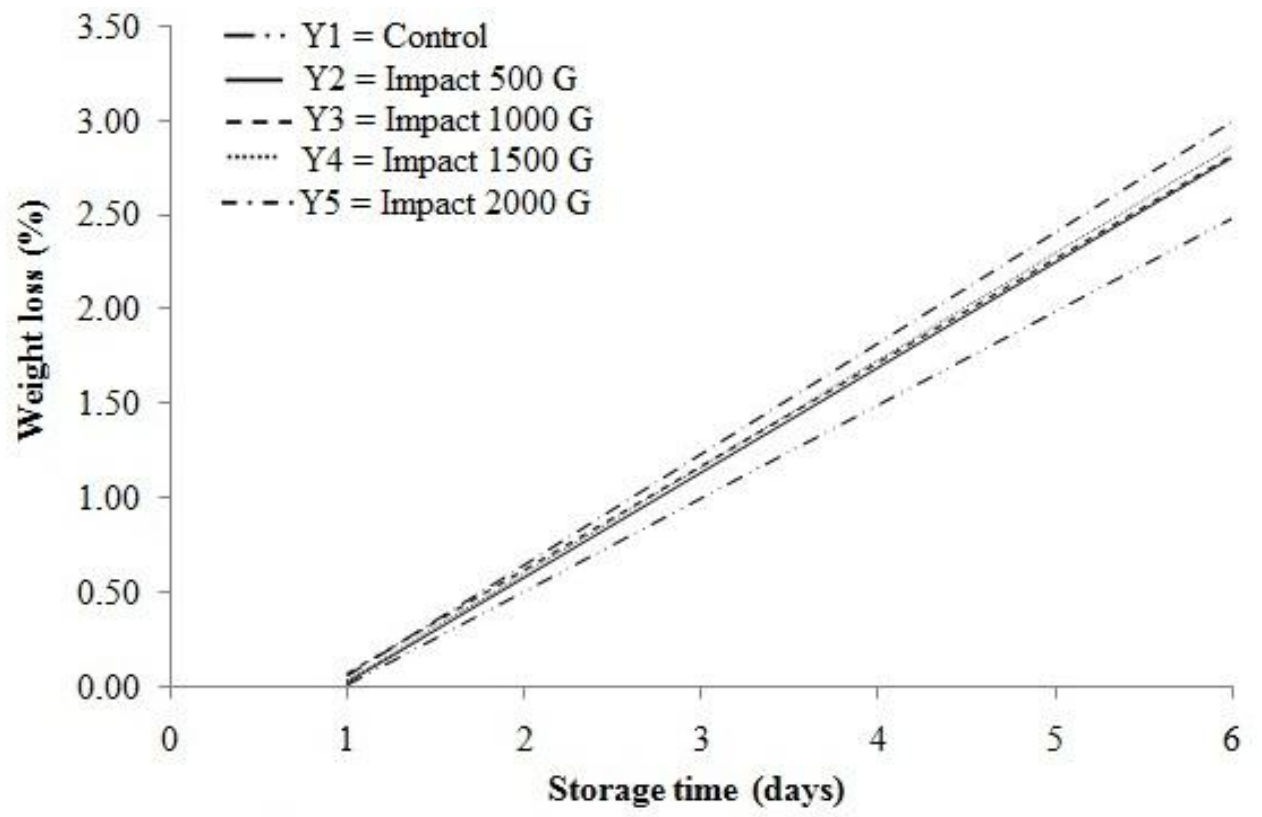

$\mathbf{Y l}=0.4929 \mathrm{x}-0.4796 \mathrm{R}^{2}=0.9967 ; \mathbf{Y 2}=0.5563 \mathrm{x}-0.5287 \mathrm{R}^{2}=0.9969 ; \mathbf{Y 3}=0.5479 \mathrm{x}-0.469 \mathrm{R}^{2}=0.9925$;

$\mathbf{Y} 4=0.5652 \mathrm{x}-0.5295 \mathrm{R}^{2}=0.99841 ; \mathbf{Y} 5=0.5863 \mathrm{x}-0.5232 \mathrm{R}^{2}=0.9966$

FIGURE 3.Weight loss (\%) in oranges subjected to different impact magnitudes during 6 days of storage.

Fruits subjected to impacts presented reduction in soluble solids content in relation to the control, even when low impact magnitudes were employed (Tab. 1). This study is relevant since the values of $500 \mathrm{G}$ can be obtained in only one step throughout harvest and loading. Thus, decreasing impacts before arrival at the industry can preserve soluble solids contents. Soluble solids content reduction in injured fruits can be related to the use of these compounds as respiratory substrate since there is an increase in $\mathrm{CO}_{2}$ production in relation to intact fruit (MATTIUZ \& DURIGAN, 2001). Soluble solids content decreases were also assessed in 'Montenegrina' tangerines, subjected to mechanical damage (MONTERO et al., 2009). Soluble solids content is an important attribute, among others, which can be used as a parameter for farmer payments, according to the proposals of the 2015 Agenda of Coordination and Contracts of the Citrus sector (NEVES et al., 2010).

TABLE 1.Soluble solids, titratable acidity, ascorbic acid, $\mathrm{pH}$ and firmness means in oranges, subjected to different impact magnitudes, stored at $24^{\circ} \mathrm{C} \pm 1{ }^{\circ} \mathrm{C}$ and $85 \% \pm 5 \% \mathrm{RH}$ for 6 days.

\begin{tabular}{cccccc}
\hline Treatments & Soluble solids & $\begin{array}{c}\text { Titratable } \\
\text { acidity }\end{array}$ & Ascorbic acid & $\mathrm{pH}$ & Firmness \\
\hline Control & ${ }^{\circ}$ Brix & $\mathrm{g} 100 \mathrm{~mL}^{-1}$ & $\mathrm{mg} 100 \mathrm{~mL}^{-1}$ & & $\mathrm{Kgf} \mathrm{cm}^{-2}$ \\
$500 \mathrm{G}$ & $12.63 \mathrm{a}$ & $1.15 \mathrm{a}$ & $56.42 \mathrm{a}$ & $3.54 \mathrm{a}$ & $0.61 \mathrm{a}$ \\
$1000 \mathrm{G}$ & $12.12 \mathrm{~b}$ & $1.15 \mathrm{a}$ & $56.45 \mathrm{a}$ & $3.52 \mathrm{a}$ & $0.63 \mathrm{a}$ \\
$1500 \mathrm{G}$ & $11.93 \mathrm{~b}$ & $1.09 \mathrm{~b}$ & $56.28 \mathrm{a}$ & $3.53 \mathrm{a}$ & $0.56 \mathrm{a}$ \\
$2000 \mathrm{G}$ & $12.23 \mathrm{~b}$ & $1.05 \mathrm{~b}$ & $56.99 \mathrm{a}$ & $3.55 \mathrm{a}$ & $0.52 \mathrm{a}$ \\
$\mathrm{CV}(\%)$ & $12.22 \mathrm{~b}$ & $1.05 \mathrm{~b}$ & $53.81 \mathrm{~b}$ & $3.54 \mathrm{a}$ & $0.52 \mathrm{a}$ \\
\hline & 3.3 & 6.6 & 4.6 & 2.0 & 29.3 \\
\hline & $* *$ & $* *$ & $* *$ & $\mathrm{~ns}$ & $\mathrm{Ns}$ \\
\hline
\end{tabular}

Means followed by the same letter in column do not differ from each other by the Tukey test $(\mathrm{p} \leq 0.01)$.

$* *$ Significant at $1 \%$ of probability $(\mathrm{p}<0.01)$; ns - non-significant $(\mathrm{p}>=0.01)$.

Titratable acidity and ascorbic acid content in impacts below 500G did not present significant differences in relation to the control (Tab. 1). However, a decrease in the average titratable acidity values of impacts from 1000 through $2000 \mathrm{G}$ was observed. A reduction in acid concentration during the storage period might cause a raise in citric acid production and its consumption 
(CHITARRA \& CHITARRA, 2005). In tangerines, impacts caused a significant reduction in total titratable acidity (MONTERO et al., 2009). The pH mean values remained stable (Tab. 1).

The lowest ascorbic acid value was found in fruits subjected to impacts of $2000 \mathrm{G}$ (Tab 1), significantly different from the other treatments. A decrease in ascorbic acid values was also observed in guavas, tangerines and 'Tahiti' limes subjected to injury by impact or compression (MATTIUZ \& DURIGAN, 2001; MONTERO et al., 2009).

Firmness, besides the absence of significant difference among treatments, decreased with impact magnitudes over $1000 \mathrm{G}$, with the fruits being less firm when subjected to impacts of $1500 \mathrm{G}$ and 2000G (Tab. 1). Firmness reduction in mechanically injured fruits was also detected in papayas (GODOY et al., 2010) and apples (MONTERO et al., 2009). Mechanical damage causes firmness loss due to cellular rupture and enzymatic activity (TEZOTTO et al., 2011).

Table 2. Lightness, chroma and hue angle in oranges, subjected to different impact magnitudes, stored at $24^{\circ} \mathrm{C} \pm 1{ }^{\circ} \mathrm{C}$ and $85 \% \pm 5 \% \mathrm{RH}$ for 6 days.

\begin{tabular}{lccc}
\hline Treatments & Lightness & Chroma & Hue Angle \\
\hline Control & $63.57 \mathrm{a}$ & $62.23 \mathrm{a}$ & $71.54 \mathrm{a}$ \\
$500 \mathrm{G}$ & $62.85 \mathrm{a}$ & $60.06 \mathrm{ab}$ & $70.62 \mathrm{ab}$ \\
$1000 \mathrm{G}$ & $63.30 \mathrm{a}$ & $61.23 \mathrm{ab}$ & $69.79 \mathrm{~b}$ \\
$1500 \mathrm{G}$ & $63.62 \mathrm{a}$ & $60.10 \mathrm{ab}$ & $71.53 \mathrm{a}$ \\
$2000 \mathrm{G}$ & $63.61 \mathrm{a}$ & $59.40 \mathrm{~b}$ & $71.77 \mathrm{a}$ \\
$\mathrm{CV}(\%)$ & 3.9 & 7.3 & 5.8 \\
\hline & $\mathrm{Ns}$ & $* *$ & Ns \\
\hline
\end{tabular}

Means followed by the same letter in column do not differ from each other by the Tukey test $(\mathrm{p} \leq 0.01)$.

** Significant at $1 \%$ de probability $(\mathrm{p}<0.01)$; ns - non-significant $(\mathrm{p}>=0.01)$.

Lightness remained constant during storage (Tab. 2). Chroma and hue angle showed statistically significant differences, however, with little variation and visual perception. Chroma presented insufficient reduction in fruits subjected to impacts of $2000 \mathrm{G}$ and non-relevant alterations in hue angle during storage. Similar results were described by MONTERO et al. (2009), evaluating 7 citrus species ('Murcott' tangor; 'Valencia' orange; 'Tahiti' lime; 'Michal', 'Montenegrina', 'Rainha' and 'Ponkan' tangerines) subjected to impact and compression, in which only 'Ponkan' tangerine showed color changes caused by oleocellosis. Injuries caused by impacts in apples altered epicarp color, mainly on the damaged region (MONTERO et al., 2009).

\section{CONCLUSIONS} incidence.

Alternatives to the detachment practice should be encouraged to avoid high physical damage

Loading to industry is responsible for the majority of impacts. The transfer of oranges from bulk storage to trucks was the most critical point.

Impact incidence resulted in a decrease in the soluble solids, titratable acidity, ascorbic acid and fresh weight averages.

Physical damage caused by impact throughout the harvest, picking into bags and loading for transport to the processing industry must be controlled as it interferes in postharvest quality and physiology of 'Valência' orange.

\section{ACKNOWLEDGEMENTS}

FAPESP, process 10/51155-6 for financial support. 


\section{REFERENCES}

AGRIANUAL: anuário da agricultura brasileira. São Paulo: FNP Consultoria\&Comercio, 2014. $4480 \mathrm{p}$.

AOAC- ASSOCIATION OF OFFICIAL ANALYTICAL CHEMISTS. Official methods of analysis of the $A O A C .18^{\text {th }}$. ed. 2005 revi3. Gaithersburg: AOAC International, 2010. $1 \mathrm{v}$.

CALBO, A.G.; NERY, A.A. Medida de firmeza em hortaliças pela técnica de aplanação. Horticultura Brasileira, Brasília, v.3, n.1, p.14-18, 1995.

CAMARGO, G.G.R.; FERREIRA, M. D; ANDREUCETTI, C. Testes de impacto em laboratório para tomate de mesa (Lycopersicon esculentum Mill.) cultivar Débora. Horticultura Brasileira, Brasília, v.22, n.2, 2004.

CHITARRA, M. I. F.; CHITARRA, A. B. Pós-colheita de frutas e hortaliças: fisiologia e manuseio. 2. ed. Lavras: UFLA, 2005. 783p.

COSTA, S. E. A. Análise ergonômica do trabalho de colheita de citros: comparativo dos métodos de colheita manual e semimecanizada. 2013. 171 f. Dis sertação (Mestrado em Engenharia de Produção) - Centro de Ciências Exatas e Tecnologia, Universidade Federal de São Carlos, São Carlos, 2013.

CORRÊA, I.M.; MELLO, R.C.; YAMASHITA, R.Y.; RAMOS; H.H. Modificação de escada visando a melhoria da segurança na colheita manual de citros. Revista Brasileira de Agrociência, Pelotas, v.15, n.1, p.109-114, jan-dez, 2009.

DURIGAN, M. F. B.; MATTIUZ, B.; DURIGAN, J. F. Injúrias mecânicas na qualidade póscolheita de lima ácida 'Tahiti' armazenada sob condição ambiente. Revista Brasileira Fruticultura, Jaboticabal, v. 27, n. 3, 2005.

FERREIRA, M. D.; MAGALHÃES P. S. G. Colheita. In: FERREIRA, M. D. (Editor). Colheita e beneficiamento de frutas e hortaliças. São Carlos: Embrapa Instrumentação Agropecuária, 2008. p. 13-22.

FERREIRA, M. D.; CAMARGO, G. G. T.; ANDREUCCETTI, C.; MORETTI, C. L. Determinação em tempo real da magnitude de danos físicos por impacto em linhas de beneficiamento e em condições de laboratório e seus efeitos na qualidade de tomate. Engenharia Agrícola, Jaboticabal, v.29, n.4, p.630-641, 2009.

FISCHER, I.H.; FERREIRA, M. D.; SPOSITO, M. B.; AMORIM, L. Citrus postharvest diseases and injuries related to impact on packing lines. Scientia Agricola, Piracicaba, v.66, n.2, p. 210-217. 2009.

GODOY DE, A.E.; JACOMINO, A.P.; PEREIRA, E.C.C.; GUTIERREZ, A. S.D.; VIEIRA, C.E.M.; FORATO, L. A. Injúrias mecânicas e seus efeitos na qualidade de mamões Golden. Revista Brasileira de Fruticultura, Jaboticabal, v. 32, n. 3, p. 682-691, 2010.

IBRAF. Instituto Brasileiro de Frutas. Cresce a exportação mineira de suco de laranja. 2010 Disponível em: http://www.ibraf.org.br/estatisticas/Export_Processadas. Online. Acesso em: 25 jun. 2012.

MATTIUZ, B.; DURIGAN, J. F. Efeito de injúrias mecânicas no processo respiratório e nos parâmetros químicos de goiabas 'Paluma' e 'Pedro Sato'. RevistaBrasileira de Fruticultura,Jaboticabal, v. 23, n. 2, p. 282-287, 2001.

MILIND, S. L. Citrus fruit - Biology, Technology and Evaluation, pp.593. Else vier. 2010.

MONTERO, C. R. S; SCHWARZ, L. L.; SANTOS, L.C.; ANDREAZZA, C. S.; KECHINSKI, C. P.; BENDER, R. J. Postharvest mechanical damage affects fruit quality of 'Montenegrina' and 'Rainha' tangerines. Pesquisa Agropecuária Brasileira, Brasília, v.44, n.12, p.1636-1640, 2009. 
NEVES, M. F.; TROMBIN, V. G.; MILAN, P.; LOPES, F. F.; PEREIRA, F. C; KALAKI, R. B. $O$ Retrato da citricultura brasileira. RibeirãoPreto: Editora Marcos Fava Neves, 2010. 137 p.

PRUSKY, D. Reduction of the incidence of postharvest quality losses, and future prospects. Food Security, Oxford, v. 3, 4 , pp 463-474. 2011.

SAS INSTITUTE. SAS/IML Software: usange and reference, version 6. Cary, 1989.501 p. STATSOFT.Statistica: data analysis software system, version 10. Tulsa, 2011.

SMILANICK, J.; MANSOUR, M.; GABLER, F.; SORENSON, D. Control of citrus postharvest green mold and sour rot by potassium sorbate combined with heat and fungicides.PostharvestBiologyand Technology, Amsterdam, v. 47, 2: p. 226-238. 2008.

TEZOTTO, J.V.; JACOMINO, A.P;GODOY, A.E.;CERQUEIRA-PEREIRA, E.C.;GALLON, C. Z. Efeito do corte como dano mecânico na qualidade e na fisiologia de mamões 'golden'. Revista Brasileira de Fruticultura, Jaboticabal, v. 33, p. 241-247, (2011).

TACHIBANA, A.; RIGOLIN, A. de T.; Análise da produtividade das operações de colheita e carregamento mecanizado de laranja. Laranja, Cordeirópolis, v. 23, n. 1, p. 57-75, 2002. 